\title{
Performance Test on Mixed Refrigerant in Domestic Refrigerator
}

\author{
J.Melvin Jones ${ }^{1}$, T. Vasanthakumar ${ }^{2}$, S.Somasundaram ${ }^{3}$, S.Yadhavakumar ${ }^{4}$, \\ V.Usha ${ }^{5}$, \\ Department of Mechanical Engineering Jay Shriram Group of Institutions, Tirupur Tamilnadu 1,2,3,4,5
}

\begin{abstract}
Refrigerator is a household appliance used to preserve the foods, vegetables, beverages at low temperature. Refrigerant is the blood of the refrigerator and it changes its phase to transfer heat for giving cooling effect inside the refrigerator. Generally many refrigerator works under the vapour compression cycle and it uses only one refrigerant. Each and every refrigerant used in the refrigerator must have disadvantages, to overcome this problem we use mixed refrigerant (two different refrigerants with different properties are mixed together). In this project combination of R600a (isobutane) and R134a (1, 1, 1, 2-tetrafluroethane) is selected as a mixed refrigerant. R600a have some good properties like zero ODP, zero GWP and high latent heat of vapourization and R134a is non-toxic, non-flammable, non-corrosive and zero ODP.
\end{abstract}

Keywords: Domestic refrigerator, R134a and R600a, heat transfer.

\section{INTRODUCTION}

The basic purpose of refrigeration is to remove heat from a particular place. Refrigeration is a process of removing heat from a closed medium and rejected into the ambient medium. Refrigeration has many applications, from which one of the important application is domestic refrigerators.Basically a domestic refrigerator works under a condition of vapour compression refrigeration system. The challenge in refrigeration system is to remove heat from a low temperature source and reject it at a high temperature source. Vapour compression refrigeration cycle has advantage that highly compressed refrigerant at one temperature will tend to get colder when they are allowed to expand. Vapour compression refrigeration cycles specifically have two additional advantages. First, it absorb the large amount of thermal energy required to change a liquid to a vapour so we can easily remove the heat out of our refrigeration space.Second, the isothermal nature of the vapourization allows extraction of heat without raising the temperature of the working fluid to the temperature of whatever is being cooled. This is benefit because the close the working fluid temperature approaches that of the surroundings, the lower the rate of heat transfer. The specific working fluid used in the vapour compression refrigeration system is refrigerant. All vapour compression refrigeration systems consists of four basic components along with the interconnecting piping. These are the evaporator, condenser, compressor and the expansion valve. The functions of the four main components of an ideal vapour compression refrigeration system as follows: Compressor: The semi hermetic single cylinder reciprocating compressor used in this vapour compression refrigeration system. It sucks the low temperature and low pressure refrigerants and delivers it as high pressure and high temperature refirgerants. It has many parts such as piston, cylinder, inlet valve, exit valve, connecting rod, crank, piston pin, crank pin and crankshaft. Finally the low pressure saturated vapour is compressed to a high pressure superheated vapourin isentropic process. Condenser: It is one of the major operating component in domestic refrigerator which is used to remove the heat from the high temperature and high pressure refrigerant. Generally the condenser located at backside of the domestic refrigerator. In domestic refrigerator we used air cooled type condenser for remove the heat from the refrigerant. Finally the high pressure superheated vapour is sub-cooled saturated vapour state and then condenses into a saturated liquid state under constant pressure process. Expansion valve: An another basic component of the vapour compression refrigeration system is expansion device. The basic functions of expansion valve is to reduce the pressure from condenser pressure to evaporator pressure and regulate the flow of the refrigerant. The several types of expansion devices are hand expansion valve, capillary tubes, automatic exapansion valve, thermostatic expansion valve, float type expansion valve and electronic expansion valve. In domestic refrigerators we use capillary tubes. With the use of capillary tube the high pressure saturated liquid is expanded to a low pressure and temperature liquid-vapour mixture at constant enthalpy. Evaporator: The process of heat removal from refrigerated space is done by evaporator with the use of refrigerant. If the latent heat of vapourization of the refrigerant is high, the 
refrigeration effect would be high. Because the high latent heat of vapourization refrigerants will absorb more amount of heat while it transfer from liquid to vapour. Finally the low-pressure two-phase mixture boils to saturated vapour under constant pressure.
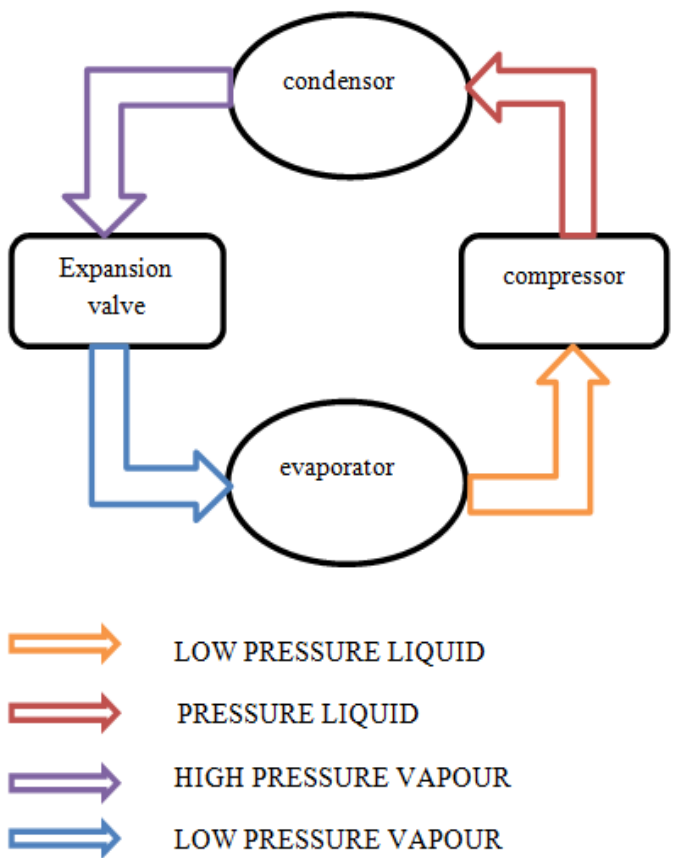

Figure 1 vapour compression system

\section{REFRIGERANT}

Refrigerant is the blood of the refrigerator. It can readily be converted from liquid into a vapour (evaporation) and also from a vapour into a liquid (condensation) within a narrow range of pressures. Refrigerants are those fluids, which are used as fluids, for example in vapour compression refrigeration systems.

Now a days in India we use R134a refrigerant in domestic refrigerator due to its excellent thermodynamic and thermo physical properties. R134a is a hydrofluorocarbon that has zero ozone depletion potential and a little global warming potential is about 1300. Its chemical formula is $\mathrm{CF}_{3} \mathrm{CH}_{2} \mathrm{~F}$. $\mathrm{R} 134 \mathrm{a}$ has some good properties they are non flammable, non explosive, good chemical stability and toxicity within limits. The refrigeration effect of R134a is $22 \%$ more than the R12 refrigerant. The mass flow rate of R134a is $18 \%$ less than $\mathrm{R} 12$. The power requirement for producing ton of refrigeration is also less than other refrigerants.

R600a (isobutene or i-butane) also known as methyl propane. Its chemical formula is $\mathrm{C}_{4} \mathrm{H}_{10}$ and is an isomer of butane. The reason behind for choosing R600a is in the project, it is odorless and colorless gas. The ozone depletion potential for R600a is zero and the global warming potential is very low. Now the fourth generation refrigerants focus on the global warming potential, ozone depletion potential, non flammable, non toxic, efficient and good stability. The R600a refrigerant is long term alternative for chlorofluorocarbons, hydro fluorocarbons and hydro chlorofluorocarbons. Because it will increases the system performance, the energy efficiency and environmental impacts. The latent heat of vapourization for R600a is high so it will give large amount of refrigeration effect. But R600a has one disadvantage that is flammability. The explosive limits of R600a (iso butane) is $1.4-$ $8.3 \%$. If we use R600a refrigerant within $100 \mathrm{gms}$, it should not a flammable one.

In this project, we take $60 \%$ of R600a and $40 \%$ of $\mathrm{R} 134 \mathrm{a}$ for increase coefficient of the performance of the system. These two refrigerants are easily available ans cheap and also has better thermodynamic and thermo physical properties.

\section{EXPERIMENTAL SETUP}

The refrigerator used in this experiment was designed by whirlpool and the capacity of the refrigerant is 175 liters. The type of compressor used in this refrigerator is single cylinder reciprocating type and this refrigerator has a five star rating for energy consumption. The mixed refrigerants (R134a \& R600a) used in this refrigerator is the proportion of 60:40. The refrigerator is placed in a room where the refrigerator is exposed to atmospheric temperature and pressure.

\begin{tabular}{|c|c|}
\hline Capacity of refrigerator & 1 \\
\hline Base Refrigerants & 3 \\
\hline 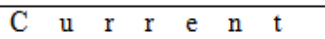 & 0 \\
\hline $\begin{array}{lllllll}\mathrm{V} & 0 & 1 & \mathrm{t} & \mathrm{a} & \mathrm{g} & \mathrm{e}\end{array}$ & $1660 \mathrm{~V}-260 \mathrm{~V}$ \\
\hline P o w e r in pu t & 9 \\
\hline $\begin{array}{llllllllll} & \mathrm{r} & \mathrm{e} & \mathrm{q} & \mathrm{u} & \mathrm{e} & \mathrm{n} & \mathrm{c} & \mathrm{y}\end{array}$ & $\mathrm{H}$ \\
\hline 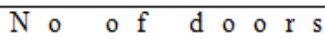 & 1 \\
\hline Defrost system & Auto defrost system \\
\hline Capillary tube length & 2 \\
\hline Capillary tube diameter & $\mathrm{m}$ \\
\hline Charged mass of refrigerant & 1 \\
\hline Compressor type & Single cylinder, Reciprocating \\
\hline
\end{tabular}

Table 1 specifications of refrigerator 


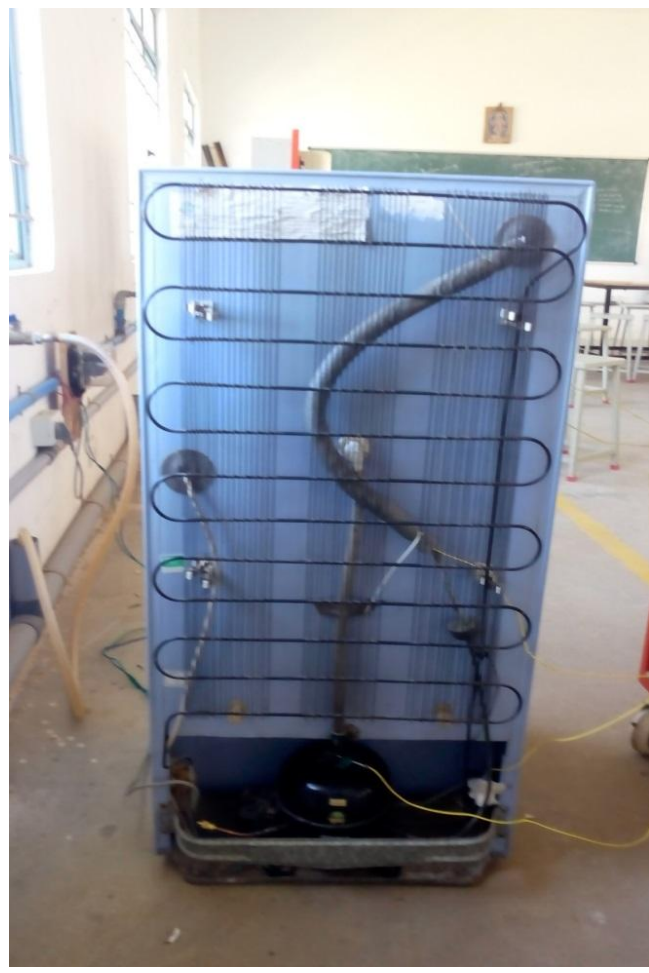

Figure 2 Domestic refrigerator

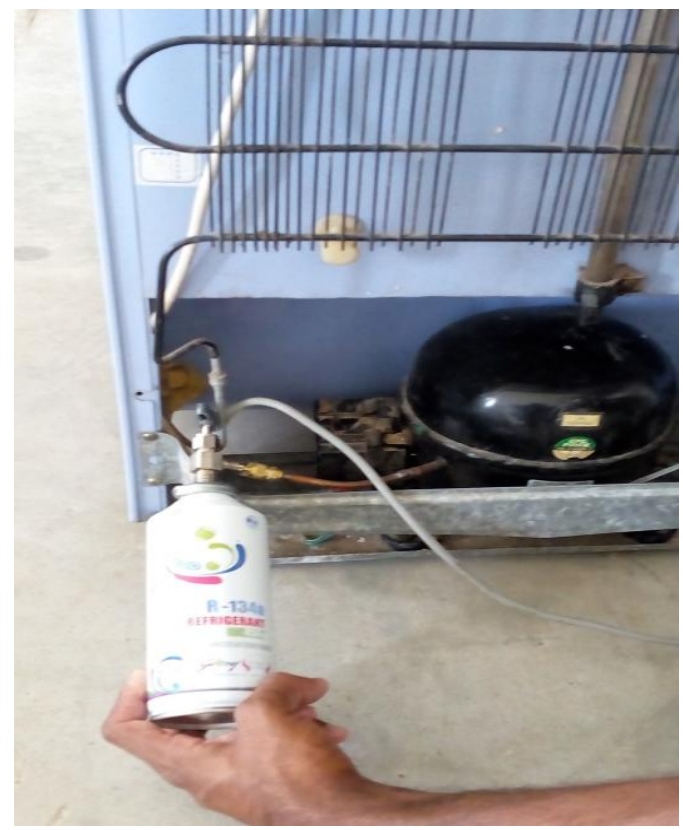

Figure 3 refrigerant charging vessel

Isobutane (R600a) is a naturally occurring refrigerant. Isobutane (R600a) and 1,1,1,2 tetrafluroethane (R134a) are the two mostly discussed and researched refrigerants for the future. The domestic refrigerator for this project is purchased from shiv electronics in palladam. R600a is purchased from sun rise electronics and R134a is purchased from the Bellaire solutions in Coimbatore.

\section{METHODOLOGY}

In this project, we used a $175 \mathrm{~L}$ whirlpool refrigerator for our experiment. It has a five star rating for energy consumption, which means it is a low power consuming system. The refrigerants used are R600a (Isobutene) and R134a (1, 1, 1, 2Tetrafluroethane) which are mixed together in the compressor.

The evacuation process is to be done before charging the refrigerant in compressor because air or non-condensable gases in the refrigerant cause a decrease in cooling capacity and a rise in input power due to high discharge pressure. In particular, atmospheric air cause the generation of sludge and shortening of compressor life. Therefore, the noncondensable gas in refrigeration cycle must not exceed $1 \%$. The suitable vacuum degree is $0.08 \mathrm{~mm}$ $\mathrm{Hg}$, and the evacuation time must be 40 minutes or more. The capacity of vacuum pump of $30 \mathrm{~L} / \mathrm{min}$ or more and it is better to vacuum simultaneously in high and low pressure sides with a pump per system. We evacuated refrigerator simultaneously from suction and discharge points for at least 50 minutes.

Now the new refrigerant is feed into the compressor by using the same vacuum pump and a non-return valve to prevent the back flow of the refrigerant. Once the required quantity of typeA refrigerant is filled in, then the type $B$ refrigerant is feed into the compressor by same process. The type A refrigerant is R600a ans it is pumped into a compressor by an non return valve with a preselected quantity. In our project we selected $75 \mathrm{~g}$ of R600a refrigerant which is $60 \%$ of total volume consumed by the refrigerator. After that the type $\mathrm{B}$ refrigerant (R134a) is pumped into a compressor by non return valve and vacuum pump with preselect quantity of $50 \mathrm{~g}$ which is the $40 \%$ of total volume consumed by the refrigerator. Now the both refrigerants are mixed up together and used in domestic refrigerator. If the refrigerant charging amount is exceeds or lacks compare to the original amount, it will cause loss of cooling capacity, lowering efficiency and damage the compressor life.

Since both the refrigerants are chemically inert, they do not react chemically with each other. The refrigerator is allowed run for another 8 hours continuously to reach a stable condition. Once the refrigeration operation is stable, the various temperatures are observed for calculation.

\section{VALUES OBSERVED}

The below table shows the values of temperature at various parts of an refrigerator and their corresponding temperatures are given below,

$\mathrm{T}_{1}$-Condenser temperature

$\mathrm{T}_{2}$-Compressor dome temperature

$\mathrm{T}_{3}$-Evaporator temperature

$\mathrm{T}_{4}$-Freezer temperature

$\mathrm{P}_{1}$ - suction pressure 
$\mathrm{P}_{2}$ - Discharge pressure of compressor

\begin{tabular}{|c|c|c|c|c|c|}
\hline $\mathrm{T}_{1}{ }^{0} \mathrm{C}$ & $\mathrm{T}_{2}{ }^{0} \mathrm{C}$ & $\mathrm{T}_{3}{ }^{0} \mathrm{C}$ & $\mathrm{T}_{4}{ }^{0} \mathrm{C}$ & $\begin{array}{l}\mathrm{P} \\
(\text { bar) }\end{array}$ & $\begin{array}{l}\mathrm{P} \\
\text { (bar) }\end{array}$ \\
\hline 35.4 & 47.3 & -15 & -6.4 & 0.59 & 0.61 \\
\hline 35.4 & 46.1 & -16 & -6.1 & 0.59 & 0.61 \\
\hline 35.5 & 45.5 & -15.6 & -6.6 & 0.59 & 0.61 \\
\hline
\end{tabular}

Table 2 Observed readings for R600a and R134a refrigerants

\begin{tabular}{|c|c|c|c|c|c|}
\hline $\mathrm{T}_{1}{ }^{0} \mathrm{C}$ & $\mathrm{T}_{2}{ }^{0} \mathrm{C}$ & $\mathrm{T}_{3}{ }^{0} \mathrm{C}$ & $\mathrm{T}_{4}{ }^{0} \mathrm{C}$ & $\begin{array}{l}\mathrm{P} \\
\text { (bar) }\end{array}$ & $\begin{array}{l}\mathrm{P} \\
\text { (bar) }\end{array}$ \\
\hline 4 & 7 & & -2.3 & 0.59 & 0.61 \\
\hline
\end{tabular}

Table 3 Observed readings for R134a refrigerant.

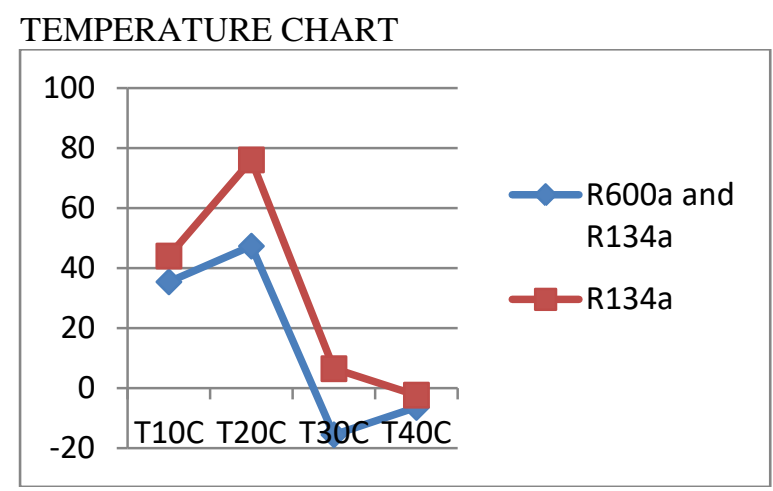

R600a

\section{CALCULATION}

At $\mathbf{T}_{\mathbf{1}}=35.4^{\mathbf{0}} \mathrm{C}$

From refrigeration table, for R600a $\mathrm{hf}_{1}=283.675 \mathrm{~kJ} / \mathrm{kg}$

$\mathrm{hg}_{1}=601.205 \mathrm{KJ} / \mathrm{Kg}$

$\mathrm{hfg}_{1}=\mathrm{hg} 1-\mathrm{hf} 1$

hfg $_{1}=601.205-283.675$

$\mathrm{hfg}_{1}=317.53 \mathrm{KJ} / \mathrm{Kg}$

$\mathrm{h}_{1}=283.675+(0.5 \times 317.53)$

$\mathrm{h}_{1}=442.44 \mathrm{KJ} / \mathrm{Kg}$

\section{At $\mathbf{T}_{\mathbf{2}}=\mathbf{4 7 . 3 ^ { 0 } \mathrm { C }}$}

From refrigerant table, for R600a

$\mathrm{hf}_{2}=314.245 \mathrm{KJ} / \mathrm{Kg}$

$\mathrm{hg}_{2}=616.45 \mathrm{KJ} / \mathrm{Kg}$

$\mathrm{hfg}_{2}=616.45-314.25=302.695 \mathrm{KJ} / \mathrm{Kg}$

$\mathrm{h}_{2}=\mathrm{hf}_{2}+\mathrm{x}_{2} \mathrm{hfg}_{2}$

$\mathrm{h}_{2}=314.25+(0.5 \times 302.65)$

$\mathrm{h}_{2}=465.5975 \mathrm{KJ} / \mathrm{Kg}$

\section{At $\mathbf{T}_{3}=-\mathbf{1 5 . 5}{ }^{0} \mathrm{C}$}

From refrigerant table, for R600a

$\mathrm{h}_{3}=\mathrm{hf}_{3}+\mathrm{x}_{3} \mathrm{hfg}_{3}$

$\mathrm{hf}_{3}=164.916 \mathrm{KJ} / \mathrm{Kg}$

$\mathrm{hg}_{3}=533.4288 \mathrm{KJ} / \mathrm{Kg}$

$\mathrm{hfg}_{3}=368.51 \mathrm{KJ} / \mathrm{Kg}$

$\mathrm{h}_{3}=164.16+(0.5 \times 368.51)$

$\mathrm{h}_{3}=349.17 \mathrm{KJ} / \mathrm{Kg}$
Coefficient of performance

cop $=\frac{(\mathrm{h} 1-\mathrm{h} 3)}{(h 2-h 1)}$

Refrigeration effect $=\mathrm{h}_{1}-\mathrm{h}_{3}$

Work input $=\mathrm{h}_{2}-\mathrm{h}_{1}$

$$
=93.27 \mathrm{KJ} / \mathrm{Kg}
$$

$$
=23.1575 \mathrm{KJ} / \mathrm{Kg}
$$

Coefficient of performance $=93.27 / 23.1575$

$$
\mathbf{C O P}=4.0276
$$

\section{R 134a}

\section{At $\mathbf{T}_{\mathbf{1}}=35.4{ }^{\mathbf{0}} \mathrm{C}$}

From refrigeration table, for $\mathrm{R} 134 \mathrm{a}$

$\mathrm{hf}_{1}=249.01 \mathrm{~kJ} / \mathrm{kg}$

$\mathrm{hg}_{1}=417.185 \mathrm{KJ} / \mathrm{Kg}$

$\mathrm{hfg}_{1}=$ hg1-hf1

$\mathrm{hfg}_{1}=417.85-249.01$

$\mathrm{hfg}_{1}=168.175 \mathrm{KJ} / \mathrm{Kg}$

$\mathrm{h}_{1}=249.01+(0.5 \times 168.175)$

$\mathrm{h}_{1}=333.075 \mathrm{KJ} / \mathrm{Kg}$

At $\mathbf{T}_{2}=47.3^{\circ} \mathrm{C}$

From refrigerant table, for $\mathrm{R} 134 \mathrm{a}$

$\mathrm{hf}_{2}=267 \mathrm{KJ} / \mathrm{Kg}$

$\mathrm{hg}_{2}=422.305 \mathrm{KJ} / \mathrm{Kg}$

$\mathrm{hfg}_{2}=422.305-267=155.305 \mathrm{KJ} / \mathrm{Kg}$

$\mathrm{h}_{2}=\mathrm{hf}_{2}+\mathrm{x}_{2} \mathrm{hfg}_{2}$

$\mathrm{h}_{2}=267+(0.5 \times 155.305)$

$\mathrm{h}_{2}=344.6525 \mathrm{KJ} / \mathrm{Kg}$

\section{At $\mathbf{T}_{\mathbf{3}}=\mathbf{- 1 5 . 5}{ }^{\mathbf{0}} \mathrm{C}$}

From refrigerant table, for $\mathrm{R} 134 \mathrm{a}$

$\mathrm{h}_{3}=\mathrm{hf}_{3}+\mathrm{x}_{3} \mathrm{hfg}_{3}$

$\mathrm{hf}_{3}=180.135 \mathrm{KJ} / \mathrm{Kg}$

$\mathrm{hg}_{3}=38.63 \mathrm{KJ} / \mathrm{Kg}$

$\mathrm{hfg}_{3}=209.405 \mathrm{KJ} / \mathrm{Kg}$

$\mathrm{h}_{3}=180.135+(0.5 \times 20.405)$

$\mathrm{h}_{3}=284.8825 \mathrm{KJ} / \mathrm{Kg}$

Coefficient of performance

cop $=\frac{(h 1-h 3)}{(h 2-h 1)}$

Refrigeration effect $=\mathrm{h}_{1}-\mathrm{h}_{3}$

Work input $=\mathrm{h}_{2}-\mathrm{h}_{1}$

$$
=48.215 \mathrm{KJ} / \mathrm{Kg}
$$

$$
=11.555 \mathrm{KJ} / \mathrm{Kg}
$$

Coefficient of performance $=48.215 / 11.555$

$$
\text { COP }=4.172
$$

Refrigerant effect $=(93.27 * 60 / 100)+$ $(48.125 * 40 / 100)$

$$
=75.212 \mathrm{KJ} / \mathrm{Kg}
$$

Work input $=(23.1575 * 60 / 100)+(11.555 * 40 / 100)$

$$
=18.5165 \mathrm{KJ} / \mathrm{Kg}
$$

Coefficient of performance $=(4.0276 * 60 / 100)+$ $(4.172 * 40 / 100)$

$$
\mathbf{C O P}=4.085
$$




VI. RESULTS
\begin{tabular}{|l|l|l|l|l|l|l|}
\hline $\mathrm{T}_{1}{ }^{\circ} \mathrm{C}$ & $\mathrm{T}_{2}{ }^{\circ} \mathrm{C}$ & $\mathrm{T}_{3}{ }^{\circ} \mathrm{C}$ & $\mathrm{T}_{4}{ }^{\circ} \mathrm{C}$ & $\begin{array}{l}\text { Refrigeration } \\
\text { Effect }(\mathrm{KJ} / \mathrm{Kg})\end{array}$ & $\begin{array}{l}\mathrm{W} \text { or k d o n e } \\
(\mathrm{KJ} / \mathrm{Kg})\end{array}$ & $\mathrm{COP}$ \\
\hline 35.4 & 47.3 & -15.5 & -6.4 & 75.3 & 18.5 & 4.08 \\
\hline
\end{tabular}

Table 4 Results for R600a and R134a refrigerants

\begin{tabular}{|l|l|l|l|l|l|l|}
\hline $\mathrm{T}_{1}{ }^{\circ} \mathrm{C}$ & $\mathrm{T}_{2}{ }^{\circ} \mathrm{C}$ & $\mathrm{T}_{3}{ }^{\circ} \mathrm{C}$ & $\mathrm{T}_{4}{ }^{\circ} \mathrm{C}$ & $\begin{array}{l}\text { Refrigeration } \\
\text { Effect(KJ/Kg) }\end{array}$ & $\begin{array}{l}\text { W o r k d o n e } \\
(\mathrm{KJ} / \mathrm{Kg})\end{array}$ & $\mathrm{C} \mathrm{O} \mathrm{P}$ \\
\hline 44 & 76 & 6.5 & -2.3 & 58.725 & 19.22 & 3.01 \\
\hline
\end{tabular}

Table 5 Results for R134a refrigerant.

refrigerants (R600a and R134a) can further increase the coefficient of performance and
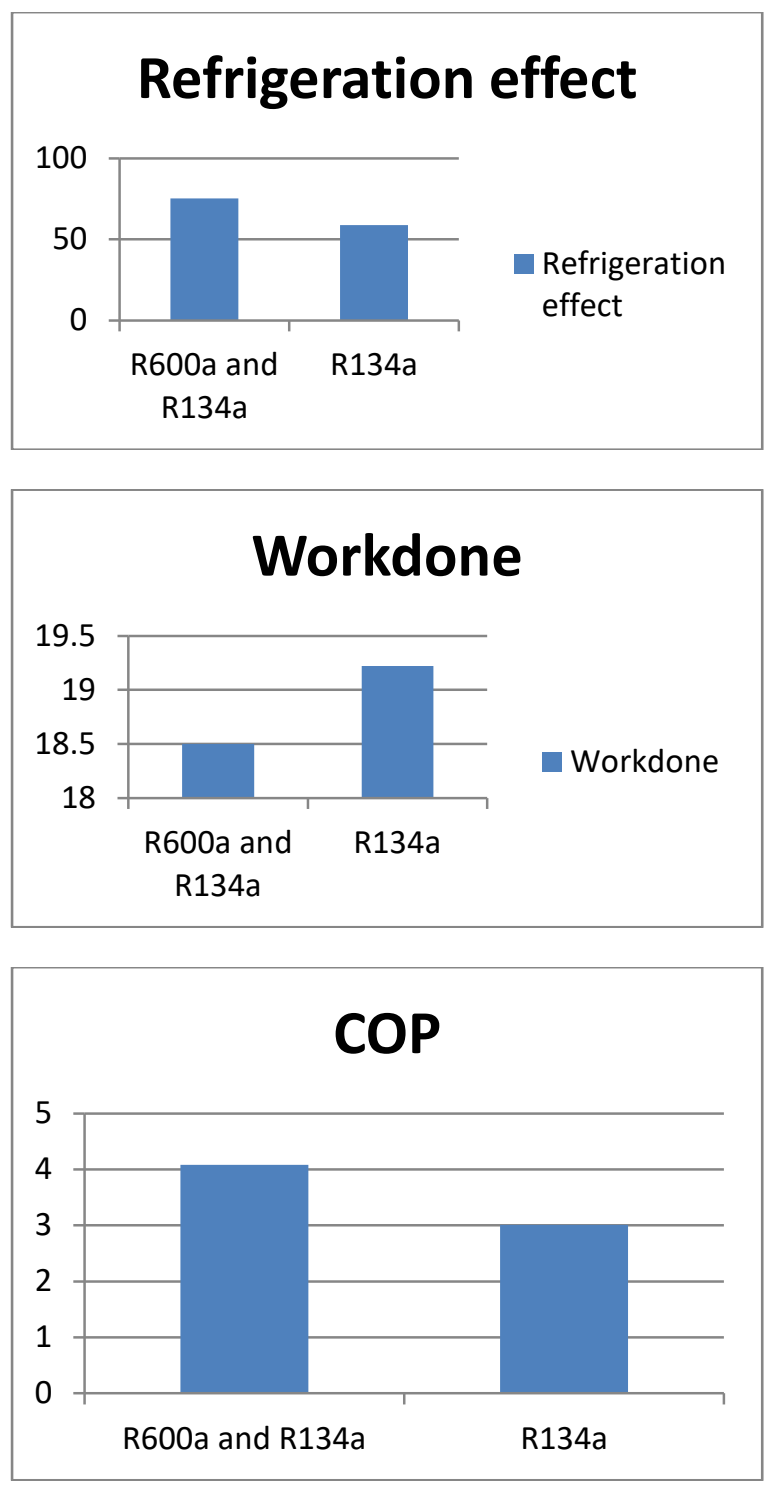

\section{CONCLUSION}

In this project it is found that R600a$\mathrm{R} 134 \mathrm{a}$ mixed refrigerants can be used as a working fluid for a domestic refrigeration system. The result shows that R600a and R134a can work normally and efficiently in a domestic refrigerator. When compared to pure R134a refrigerant, the mixed refrigeration effect with given constant work input.Thus an experiment is carried out to determine the performance of R600a and R134a mixed refrigerant and it is well explained that the mixed refrigerants can able to enhance the performance of the refrigerator.

\section{REFERENCES}

[1]. Rasti.M et.al [2011] Experimental study of $\mathrm{R} 600 \mathrm{a}$ and $\mathrm{R} 436 \mathrm{a}$ to replace $\mathrm{R} 134 \mathrm{a}$ in a domestic refrigerator and freezerInternational Chemical Engineering Congress and Exhibition.

[2]. Vicknesh.K [2016] Performance test on vapour compression refrigeration system using R290 and R134a mixtureInternational Journal of Scientific and Research Publications, volume 6 [Issue 6].

[3]. Sendilkumar.D et.al [2012] Experimental study on $\mathrm{Al}_{2} \mathrm{O}_{3}-\mathrm{R} 134 \mathrm{a}$ nano refrigerant in refrigeration system- International Journal of Modern Engineering Research, volume 2 [Issue5].

[4]. Ramesh kumar.M et.al [2016] Comparative study of R600a and blends of $(\mathrm{R} 600 \mathrm{a} / \mathrm{R} 1270)$ as domestic refrigerantsInternational Journal of Multidisciplinary Research and Modern Education, volume 2 [Issue 1].

[5]. Dong yeon lee et.al [2007] Performance characteristics of a small -capacity directly cooled refrigerator using R290/R600a (55/45)- International Journal of Refrigeration.

[6]. Ajeetkumarrai et.al [2015] Experimental study on a domestic refrigerator using LPG as a refrigerant- International Journal of Mechanical Engineering and Technology, volume 6 [Issue 11].

[7]. Akintunde M.A [2013] Experimental study of R134a, R406a and R600a blends as alternative to Freon 12- IOSR Journal of Mechanical and Civil Engineering, volume 7 [Issue 1]. 
[8]. ShrutiS.Chouhan et.al [2016] Improvement of cop and energy efficiency ratio of domestic refrigerator by using additive in refrigerant R134a- International Advanced Research Journal in Science, Engineering and Technology volume 3 [Issue 6].

[9]. Abinesh.T [2016] Performance analysis of hybrid alternative refrigerant to replace $\mathrm{R} 134 \mathrm{a}$ in domestic refrigerator- International Journal of Innovative Works in Engineering and Technology volume 2 [Issue 3].

[10]. Poojayadavet.al [2015] Exergy analysis of R134a based vapour compression refrigeration tutor- IOSR Journal of Mechanical and Civil Engineering. 